Article

\title{
Synthesis of $\mathrm{CuO} / \mathrm{ZnO}$ Nanocomposites and Their Application in Photodegradation of Toxic Textile Dye
}

\author{
Abdullah Al Mamun Sakib ${ }^{1}$, Shah Md. Masum ${ }^{1}$, Jan Hoinkis ${ }^{2}$, Rafiqul Islam ${ }^{1}$ and \\ Md. Ashraful Islam Molla 1,*iD \\ 1 Department of Applied Chemistry \& Chemical Engineering, Faculty of Engineering \& Technology, \\ University of Dhaka, Dhaka 1000, Bangladesh; abdullahsakib33@gmail.com (A.A.M.S.); \\ masumdhk@yahoo.com (S.M.M.); professorrafiqulislam@yahoo.co.uk (R.I.) \\ 2 Centre of Applied Research (CAR), Karlsruhe University of Applied Sciences, 76133 Karlsruhe, Germany; \\ jan.hoinkis@hs-karlsruhe.de \\ * Correspondence: ashraful.acce@du.ac.bd
}

Received: 23 August 2019; Accepted: 13 September 2019; Published: 17 September 2019

check for updates

\begin{abstract}
CuO} / \mathrm{ZnO}$ composites are synthesized using a simple mechanochemical combustion method X-ray diffraction (XRD), scanning electron microscopy (SEM), energy-dispersive X-ray spectroscopy (EDX), and Fourier transform infrared (FTIR) are used to characterize the prepared oxides. X-ray diffraction reveals that the prepared $\mathrm{CuO} / \mathrm{ZnO}$ exhibit a wurtzite $\mathrm{ZnO}$ crystal structure and the composites are composed of $\mathrm{CuO}$ and $\mathrm{ZnO}$. The strong peaks of the $\mathrm{Cu}, \mathrm{Zn}$, and $\mathrm{O}$ elements are exhibited in the EDX spectrum. The FTIR spectra appear at around $3385 \mathrm{~cm}^{-1}$ and $1637 \mathrm{~cm}^{-1}$, caused by $\mathrm{O}-\mathrm{H}$ stretching, and $400 \mathrm{~cm}^{-1}$ to $590 \mathrm{~cm}^{-1}$, ascribable to $\mathrm{Zn}-\mathrm{O}$ stretching. The photocatalytic performances of $\mathrm{CuO} / \mathrm{ZnO}$ nanocomposites are investigated for the degradation of methylene blue (MB) aqueous solution in direct solar irradiation. The degradation value of $\mathrm{MB}$ with $5 \mathrm{wt} \% \mathrm{CuO} / \mathrm{ZnO}$ is measured to be $98 \%$, after $2 \mathrm{~h}$ of solar irradiation. The reactive ${ }^{\bullet} \mathrm{O}_{2}{ }^{-}$and ${ }^{\bullet} \mathrm{OH}$ radicals play important roles in the photodegradation of MB. Mineralization of MB is around $91 \%$ under sunlight irradiation within $7 \mathrm{~h}$. The photodegradation treatment for the textile wastewater using sunlight is an easy technique - simply handled, and economical. Therefore, the solar photodegradation technique may be a very effective method for the treatment of wastewater instead of photodegradation with the artificial and expensive Hg-Xe lamp.
\end{abstract}

Keywords: $\mathrm{CuO} / \mathrm{ZnO}$; photodegradation; nanocomposite; methylene blue; sunlight

\section{Introduction}

It is evident that water pollution is a global environmental problem now due to the presence of different types of hazardous pollutants in it [1]. Textile wastewater, which contains huge amounts of pollutants that are very harmful to the environment, is of special research interest. The release of textile wastewater to the environment causes aesthetic problems due to the changed color of the water bodies [2]. Nanocomposites, containing oxides of metal, are of great research interest at the moment due to their high photocatalytic degradation efficiency, sustainable development characteristics, and lack of secondary pollution for water pollution treatment $[3,4]$. Recently, different types of metal oxide nanocomposites have been synthesized, such as $\mathrm{ZnO}-\mathrm{Mg}$ [5], $\mathrm{CuO} / \mathrm{ZnO}$ [6], $\mathrm{ZnO}-\mathrm{NiO}$ [7], $\mathrm{Co}_{3} \mathrm{O}_{4}-\mathrm{ZnO}$ [8], and $\mathrm{CeO}_{2}-\mathrm{ZnO}$ [9]. Saravanan et al. prepared $\mathrm{CuO} / \mathrm{ZnO}_{2} \mathrm{~V}_{2} \mathrm{O}_{5} / \mathrm{ZnO}$, and $\mathrm{ZnO} / \gamma-\mathrm{Mn}_{2} \mathrm{O}_{3}$ nanocomposites using the thermal decomposition method [10-12]. They also studied the photocatalytic degradation of rhodamine $\mathrm{B}$ under sunlight irradiation using $\mathrm{CuO} / \mathrm{ZnO}$ nanocomposite. $\mathrm{Li}$ et al. [13] synthesized $\mathrm{CuO} / \mathrm{ZnO}$ nanocomposites using the thermal decomposition method and investigated the visible light-driven photocatalytic degradation of methylene blue and 
methyl orange. Kuriakose et al. [14] prepared $\mathrm{CuO} / \mathrm{ZnO}$ nanocomposites using the carbothermal evaporation method and evaluated the photocatalytic degradation of methylene blue and methyl orange dyes under sunlight irradiation. Wang el al. [15] prepared MnO@MnOx microspheres through the solvothermal process and reported the degradation of levofloxacin under simulated sunlight irradiation. Nanocomposite photocatalytic technology can be considered a green technology and provides the advantages of abundance, including postpone electron-hole recombination, higher photocatalytic activity, and the ability to convert solar energy to chemical energy, which eventually realizes the solution of energy and environmental issues [16-21].

$\mathrm{ZnO}$ is an n-type semiconductor, having a conductivity of about $10^{-7}-10^{-3} \mathrm{~S} / \mathrm{cm}$. It has a relatively large binding energy of $60 \mathrm{meV}$. However, the main disadvantages of $\mathrm{ZnO}$ are its fast electron-hole recombination rate and inefficient utilization of sunlight that lead to a reduction in photodegradation efficiency. The photodegradation performance of $\mathrm{ZnO}$ can be increased by modifying $\mathrm{ZnO}$ with transition metals [22]. Among the various transition metals, $\mathrm{Cu}$-doped $\mathrm{ZnO}$ nanomaterials are of special interest due to the photocatalytic efficiency enhancement that creates defects in the lattice and reduces the recombination of photogenerated charge carriers [23]. $\mathrm{Cu}$ also provides plenty of advantages, such as low cost, more electronegativity than zinc, and a similar atomic size to that of zinc, and leads to better doping efficiency [24]. CuO is a natural p-type semiconductor with a narrow band gap, having a conductivity of $10^{-4} \mathrm{~S} / \mathrm{cm}$, and it can be applied in photodegradation reactions [25]. Among the various metal oxide nanocomposites, researchers are paying more attention to $\mathrm{CuO} / \mathrm{ZnO}$ because of its non-toxicity, economical benefits, and availability. It possesses high energy density and good electrical and piezoelectric properties [26,27]. $\mathrm{CuO} / \mathrm{ZnO}$ nanocomposites improve physicochemical properties, compared to pure $\mathrm{ZnO}$ and $\mathrm{CuO}$ nanostructures [14]. The formation of a $\mathrm{CuO} / \mathrm{ZnO}$ heterojunction also enhances the optical and electronic properties, which are considered to be promising applications in photocatalysis [10].

Herein, the various proportions of $\mathrm{CuO} / \mathrm{ZnO}$ nanocomposites are prepared using the mechanochemical combustion method. The synthesized composites are characterized by X-ray diffraction (XRD), scanning electron microscopy (SEM), energy-dispersive $X$-ray spectroscopy (EDX), and Fourier transform infrared (FTIR). Methylene blue (MB) is a non-biodegradable and hazardous organic compound intensively used in textile industries and, so, it is selected as the degradation target to evaluate the photocatalytic performances of the composites using sunlight. The results show that $\mathrm{CuO} / \mathrm{ZnO}$ exhibit increased photocatalytic activities, compared with $\mathrm{ZnO}$. The degradation mechanism and mineralization of the improved photocatalytic performance are also discussed.

\section{Materials and Methods}

\subsection{Chemicals}

The samples were synthesized using zinc acetate dihydrate $\left(\mathrm{Zn}\left(\mathrm{CH}_{3} \mathrm{COO}\right)_{2} \cdot 2 \mathrm{H}_{2} \mathrm{O}\right)$, oxalic acid dihydrate $\left.(\mathrm{COOH})_{2} \cdot 2 \mathrm{H}_{2} \mathrm{O}\right)$, and copper acetate $\left(\mathrm{Cu}\left(\mathrm{CH}_{3} \mathrm{COO}\right)_{2}\right)$. Methylene blue $\left(\mathrm{C}_{16} \mathrm{H}_{18} \mathrm{ClN}_{3} \mathrm{~S}\right)$ was employed in the photodegradation experiment. Three scavengers were selected: Ascorbic acid $\left(\mathrm{C}_{6} \mathrm{H}_{8} \mathrm{O}_{6}\right)$, 2-propanol $\left.\left(\mathrm{CH}_{3}\right)_{2} \mathrm{CHOH}\right)$, and $d i$-ammonium oxalate monohydrate $\left.\left(\mathrm{NH}_{4}\right)_{2} \mathrm{C}_{2} \mathrm{O}_{4} \cdot \mathrm{H}_{2} \mathrm{O}\right)$. All of the analytical grade chemicals were used without any purification.

\subsection{Fabrication of $\mathrm{CuO} / \mathrm{ZnO}$}

The mechanochemical combustion method was used to prepare $\mathrm{CuO} / \mathrm{ZnO}$. In agitate mortar, $2.195 \mathrm{~g}$ of zinc oxalate dihydrate and $2.521 \mathrm{~g}$ of acetic acid were taken. Then, the mixture was ground for 10 min to produce $\mathrm{Zn}\left(\mathrm{CH}_{3} \mathrm{COO}\right)_{2} \cdot 2 \mathrm{H}_{2} \mathrm{O}$ and $(\mathrm{COOH})_{2} \cdot 2 \mathrm{H}_{2} \mathrm{O}$ paste. In the above paste, $\mathrm{Cu}\left(\mathrm{CH}_{3} \mathrm{COO}\right)_{2}$ was added as a source of $\mathrm{Cu}$, and then the grinding process was continued for the next $10 \mathrm{~min}$ to produce a precursor of zinc oxalate-copper oxalate. The precursor powders were calcined at $500{ }^{\circ} \mathrm{C}$ for $3 \mathrm{~h}$ in the presence of air atmosphere to obtain the $\mathrm{CuO} / \mathrm{ZnO}$ composite [28]. For comparison, un-doped $\mathrm{ZnO}$ was prepared from the zinc oxalate and acetic acid paste. 


\subsection{Characterization}

The X-ray diffractometer (XRD, Ultima IV, Rigaku Corporation, Akishima, Japan) was selected to collect the diffraction patterns of materials using $\mathrm{Cu} K \alpha$ radiation $(\lambda=0.15406 \mathrm{~nm}, 40 \mathrm{KV}, 1.64 \mathrm{~mA})$ in the ranges of $10^{\circ}$ to $80^{\circ}$ of 2-theta angle. The morphologies of oxides were recorded with a scanning electron microscope (SEM, JSM-6010 PLUS/LA, JEOL Ltd., Tokyo, Japan). Elemental analysis of $\mathrm{CuO} / \mathrm{ZnO}$ was examined using a JSM-7900F SEM attached with EDX. The chemical structures of $\mathrm{CuO} / \mathrm{ZnO}$ were studied with a Fourier transform infrared (FTIR) spectrophotometer (IR Prestige-21, SHIMADZU, Kyoto, Japan).

\subsection{Evaluation of Photocatalytic Activity}

The photocatalytic experimental conditions are presented in Table 1. Briefly, the photocatalytic performance of $\mathrm{CuO} / \mathrm{ZnO}$ composites was investigated in aqueous $\mathrm{MB}$ solution using sunlight. Experiments were conducted under similar conditions on a sunny day between 11:00 and 14:00. In photodegradation, $20 \mathrm{mg}$ of photocatalyst was added into $30 \mathrm{~mL}$ aqueous $\mathrm{MB}$ of $10 \mathrm{mg} / \mathrm{L}$ in the beakers. To equilibrate the suspension, a magnetic stirrer was used in the dark for $30 \mathrm{~min}$. Then, the suspensions in the beakers were kept in sunlight for different time intervals. About $3 \mathrm{~mL}$ MB solution was withdrawn and separated with an Advantec membrane filter $0.45 \mu \mathrm{m}$. The MB concentration was calculated using a UV-visible spectrometry (UV-1700 Pharma Spec, SHIMADZU, Kyoto, Japan). The relative MB concentration $\left(C / C_{0}\right)$ was determined at the relative absorbance $\left(A / A_{0}\right)$ of $\lambda=662 \mathrm{~nm}$, according to the Beer-Lambert law, where $A_{0}$ and $A$ were the absorbance of aqueous $\mathrm{MB}$ at a starting time $\left(t_{0}\right)$ of photodegradation and at any time $t$, respectively.

The total organic carbon (TOC) was studied using Shimadzu TOC analyzer (TOC-VCPH, Kyoto, Japan). The oxidation and titration with potassium permanganate method was applied for the measurement of chemical oxygen demand (COD).

Table 1. Experimental conditions.

\begin{tabular}{cc}
\hline Methylene blue & $30 \mathrm{~mL}, 5-20 \mathrm{mg} / \mathrm{L}$ \\
Photocatalyst & $20 \mathrm{mg}$ \\
Temperature & $\sim 30^{\circ} \mathrm{C}$ \\
pH & Natural \\
Light source & Sunlight \\
Irradiation time & $0-150 \mathrm{~min}$ \\
\hline
\end{tabular}

\subsection{Detection of Active Species}

To scrutinize the reactive species that was responsible for photocatalytic degradation of $\mathrm{MB}$, three scavenger tests were done in the same procedure as discussed in the photodegradation experiment. In the scavenger tests, di-ammonium oxalate monohydrate, 2-propanol, and ascorbic acid were stipulated as $\mathrm{h}^{+}, \bullet \mathrm{OH}$, and $\bullet^{\circ} \mathrm{O}_{2}{ }^{-}$reactive species, respectively $[29,30]$.

\section{Results and Discussion}

\subsection{XRD Patterns Study}

The crystal structure of the nanomaterials was confirmed by $X$-ray diffraction. Figure 1 displays the $\mathrm{XRD}$ patterns of the $\mathrm{ZnO}$ and with different copper contents $\mathrm{CuO} / \mathrm{ZnO}$ nanocomposites. Major peaks were observed at around $31.82^{\circ}(100), 34.50^{\circ}(002)$, and $36.32^{\circ}(101)$ of the undoped $\mathrm{ZnO}$ (JCPDS no.36-1451) [31]. $\mathrm{CuO} / \mathrm{ZnO}$ nanocomposites displayed a very minor peak at $38.8^{\circ}$, which was indexed to the (111) of $\mathrm{CuO}$ [24]. With the addition of $\mathrm{Cu}$ in $\mathrm{ZnO}$, the diffraction intensities and angles changed remarkably. The diffraction peak of $\mathrm{CuO}$ (111) was found with 5 and $7 \mathrm{wt} \%$ of copper content. In addition, with increased amounts of copper, no other peaks or appreciable shifts were observed and no solid solution was formed in between $\mathrm{ZnO}$ and $\mathrm{CuO}$. The Scherrer equation was used to obtain the 
grain size of the $\mathrm{ZnO}$ and $\mathrm{CuO} / \mathrm{ZnO}$ nanocomposites. The estimated grains were found as $\sim 32.16$ and $\sim 32.13 \mathrm{~nm}$ for $\mathrm{ZnO}$ and $5 \mathrm{wt} \% \mathrm{CuO} / \mathrm{ZnO}$, respectively.

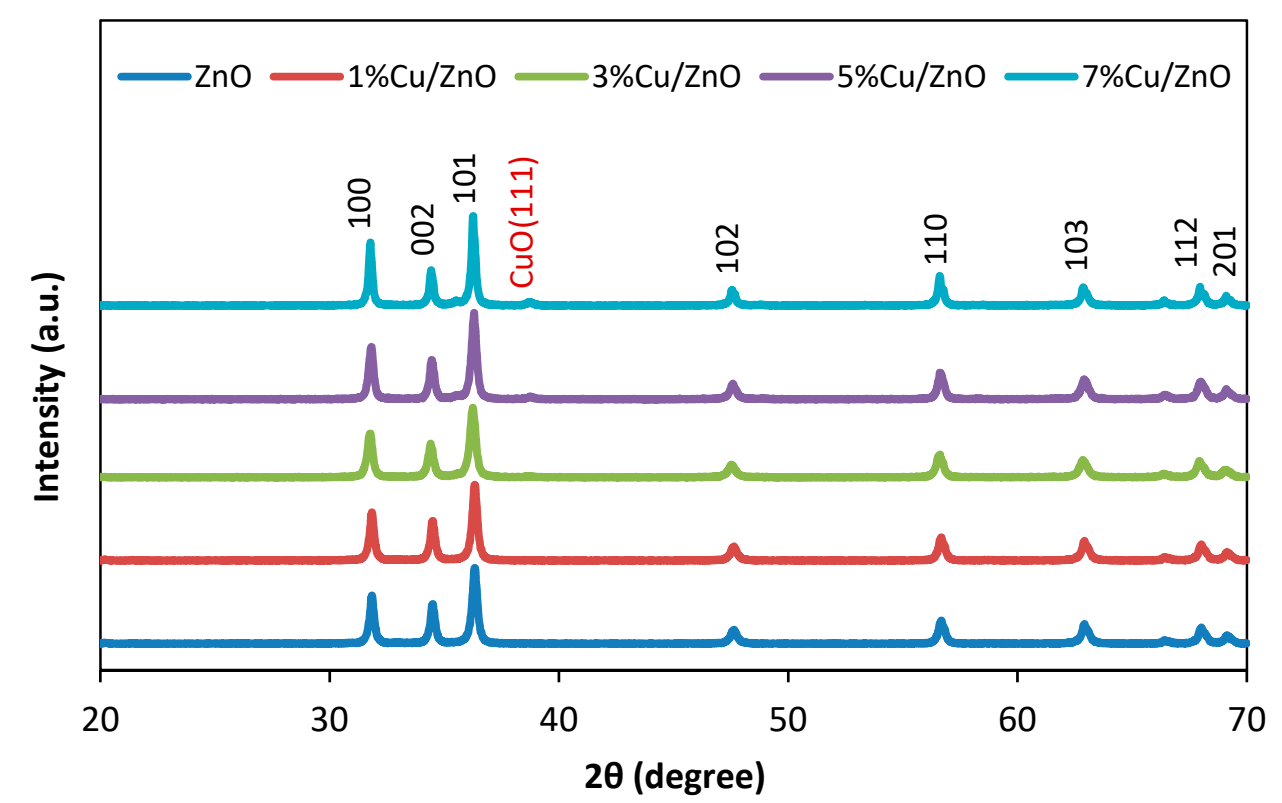

Figure 1. X-ray diffraction (XRD) patterns of $\mathrm{ZnO}$ and $\mathrm{CuO} / \mathrm{ZnO}$.

\subsection{SEM and EDX Study}

Crystal morphologies of the $\mathrm{ZnO}$ and $\mathrm{CuO} / \mathrm{ZnO}$ were evaluated through SEM. Figure 2a shows that the synthesized $\mathrm{ZnO}$ was heterogeneous with rod-shaped branches of building blocks. On the other hand, Figure $2 \mathrm{~b}$ shows that the shape of the $\mathrm{CuO} / \mathrm{ZnO}$ composite changed from rod-like to spheroid. The particle sizes of synthesized composites were in the nanometer range, which was similar to the data of XRD. Figure 2c shows the EDX line-scanning values of $\mathrm{CuO} / \mathrm{ZnO}$ heterojunction. The presences of copper, zinc, and oxygen atoms were exhibited by the EDX spectra analysis. Sharp peaks of $\mathrm{Zn}, \mathrm{Cu}$, and $\mathrm{O}$ were obtained; no other peak related to any other element was detected in the spectrum within the detection limit, which confirmed that synthesized materials were composed of $\mathrm{Zn}$, $\mathrm{Cu}$, and $\mathrm{O}$ only. The spectrum confirmed that $\mathrm{Cu}$ exists in the heterostructure, representing that the copper nanoparticles were successfully deposited on zinc oxide. 

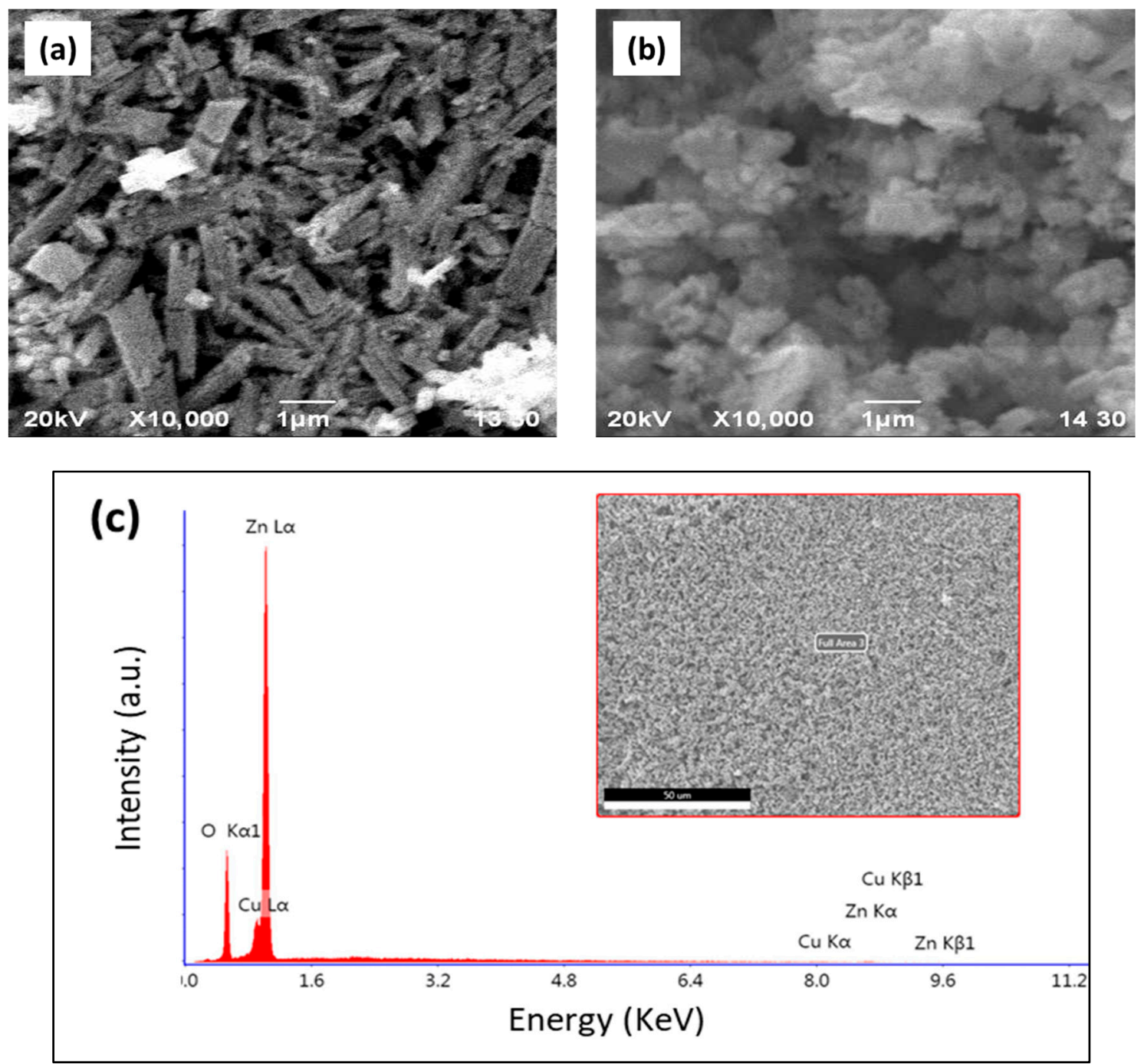

Figure 2. Scanning electron microscopy (SEM) images of (a) $\mathrm{ZnO}$ and (b) $\mathrm{CuO} / \mathrm{ZnO}$, and (c) energydispersive X-ray spectroscopy (EDX) pattern of $\mathrm{CuO} / \mathrm{ZnO}$.

\subsection{FTIR Spectral Study}

The FTIR spectra of $\mathrm{ZnO}$ and $\mathrm{CuO} / \mathrm{ZnO}$ nanocomposites are depicted in Figure 3. Generally, the absorption bands of metal oxides were below $1000 \mathrm{~cm}^{-1}$, due to inter-atomic vibrations. From Figure 3, it is seen that the absorption band of zinc oxide (stretching of $\mathrm{Zn}-\mathrm{O}$ ) was between $400 \mathrm{~cm}^{-1}$ and $590 \mathrm{~cm}^{-1}$, which confirmed the wurtzite structure of $\mathrm{ZnO}$ [32]. The vibration around $3385 \mathrm{~cm}^{-1}$ and $1637 \mathrm{~cm}^{-1}$ was attributed to asymmetric and symmetric stretching $\mathrm{H}-\mathrm{O}-\mathrm{H}$ vibration, which was due to chemisorbed water. The very weak peak at $2320 \mathrm{~cm}^{-1}$ corresponded to the symmetric $\mathrm{C}-\mathrm{H}$ bond vibrations, which may have been present due to the environmental conditions. Stretching modes of $\mathrm{C}-\mathrm{O}$ appeared at $1110 \mathrm{~cm}^{-1}$, because of the acetate group improper decomposition [33]. The bands of 3000-3650 $\mathrm{cm}^{-1}$ were attributed to reversible dissociative absorption of hydrogen on $\mathrm{Zn}$ and O [34]. 


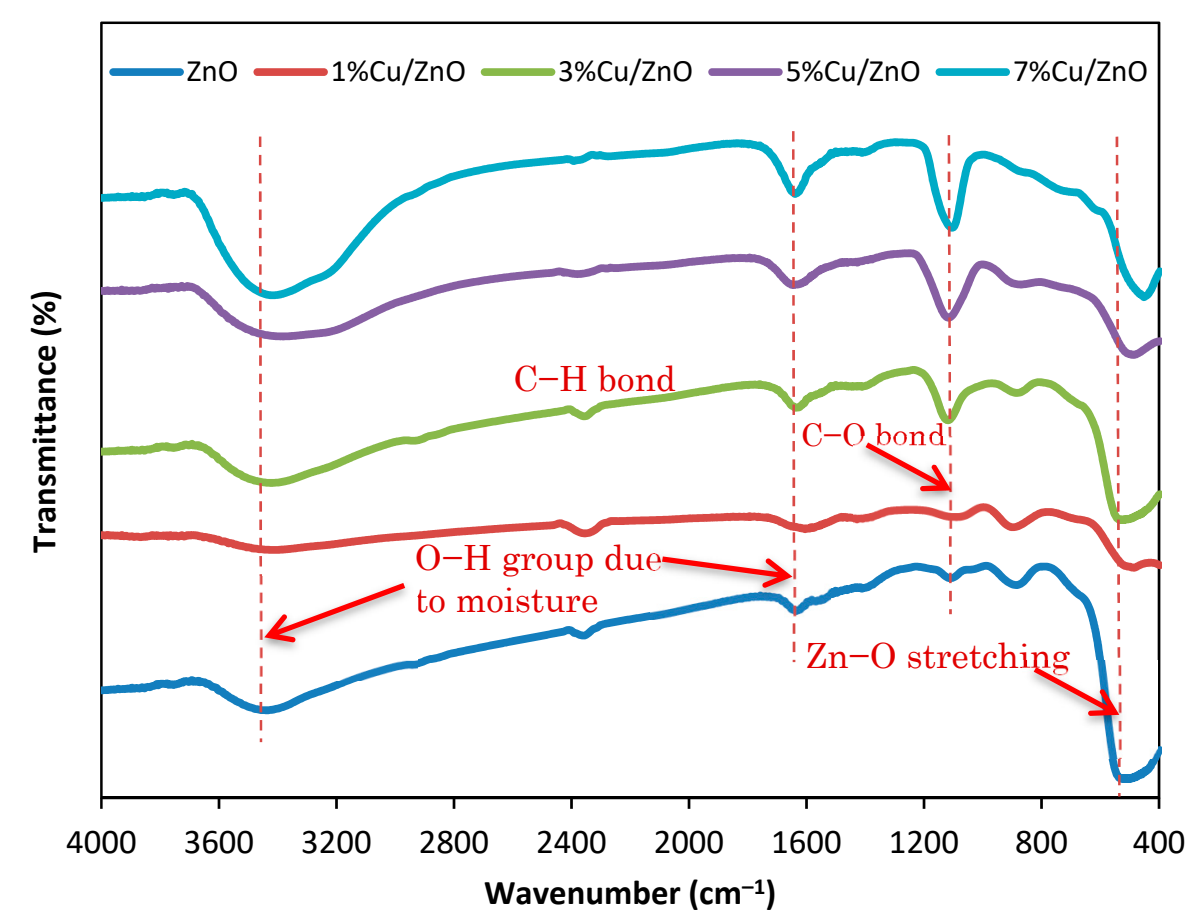

Figure 3. Fourier transform infrared (FTIR) spectra of $\mathrm{ZnO}$ and $\mathrm{CuO} / \mathrm{ZnO}$.

\subsection{UV-VIS Spectral Changes}

The absorption spectra of $\mathrm{MB}$ solution with $\mathrm{CuO} / \mathrm{ZnO}$ under sunlight irradiation are shown in Figure 4. During photolysis, pure MB was exposed $150 \mathrm{~min}$ under sunlight and it was seen that the change of the absorption spectrum was negligible. The absorption spectrum at $662 \mathrm{~nm}$ slightly decreased under dark after $150 \mathrm{~min}$ with $\mathrm{CuO} / \mathrm{ZnO}$, indicating the $\mathrm{MB}$ dye adsorption on the composite. The well-defined absorption band disappeared after $150 \mathrm{~min}$, which confirmed the MB degradation with $\mathrm{CuO} / \mathrm{ZnO}$ in the presence of sunlight.

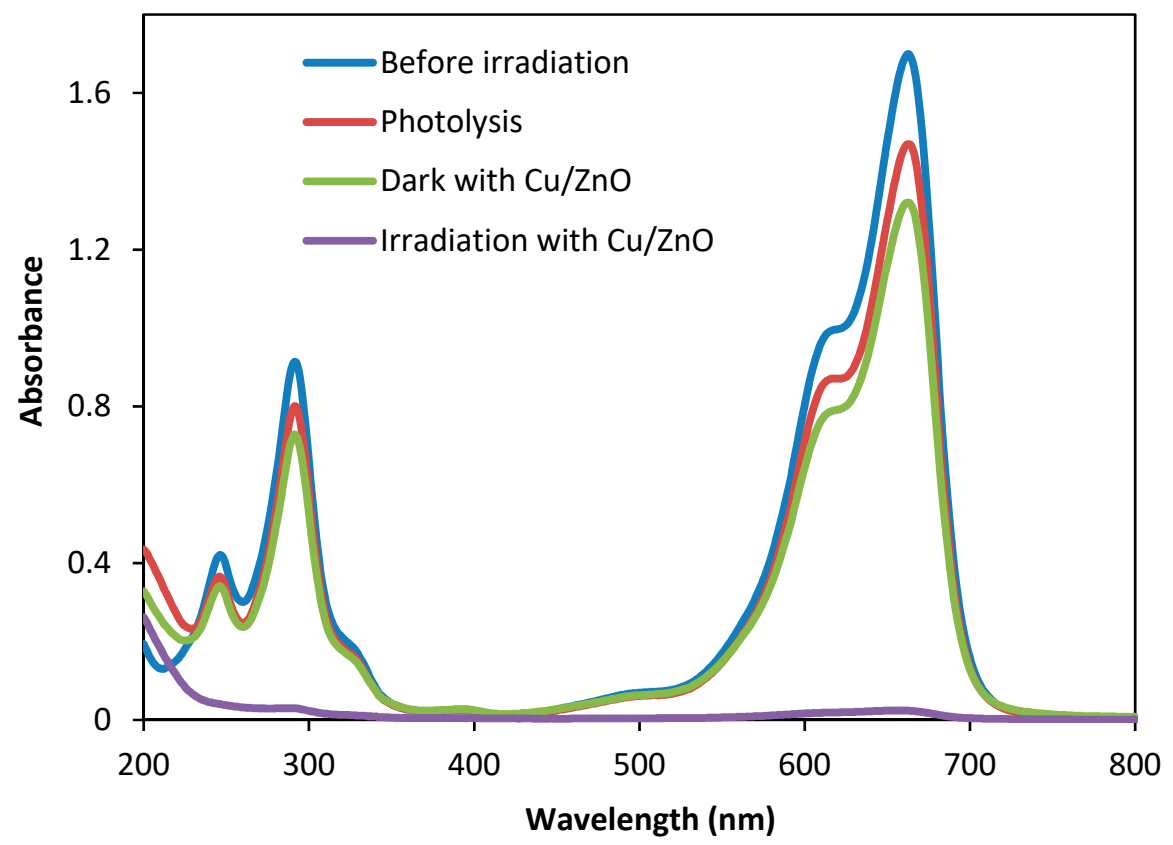

Figure 4. UV-visible spectral changes of methylene blue (MB) in water for before irradiation, photolysis, under dark, and sunlight irradiation. 


\subsection{Photocatalytic Dye Degradation}

$\mathrm{ZnO}$ and $\mathrm{CuO} / \mathrm{ZnO}$ were used in the presence of sunlight for the photodegradation of $\mathrm{MB}$ to evaluate the photocatalytic performance. The effect of the doping amounts of copper in the photodegradation of MB is depicted in Figure 5. The degradation rate increased with increasing copper amounts up to $5 \mathrm{wt} \%$ of the composite. More than $5 \mathrm{wt} \%$ of copper decreased the photocatalytic activity. This was because the $\mathrm{ZnO}$ surface was covered by the higher percentage of copper and reduced the sunlight absorption [35]. Due to efficient charge separation and higher electron transfer, $5 \mathrm{wt} \% \mathrm{CuO} / \mathrm{ZnO}$ composite showed better photocatalytic activity for MB degradation.

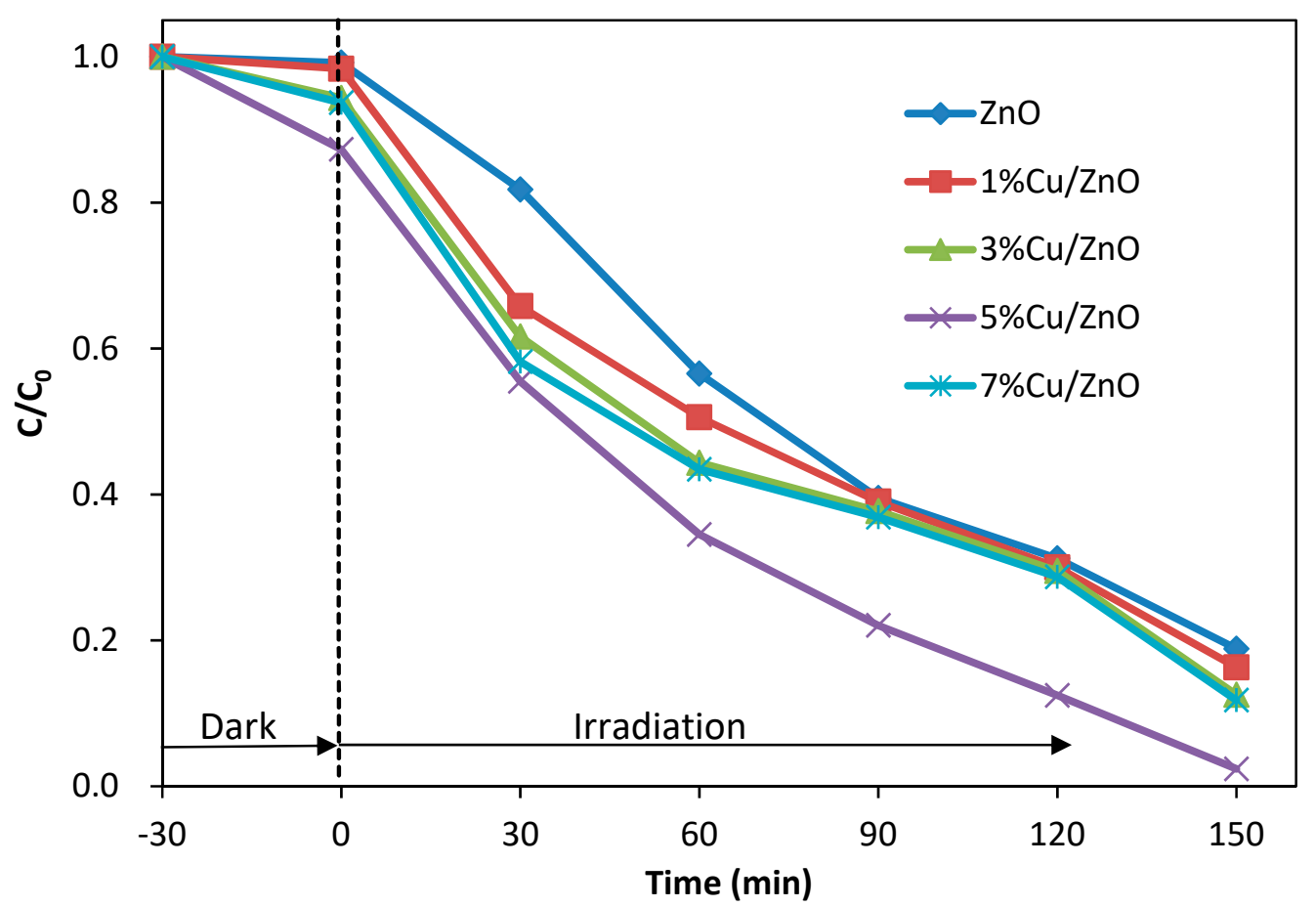

Figure 5. Photodegradation of $\mathrm{MB}$ by $\mathrm{ZnO}$ and $\mathrm{CuO} / \mathrm{ZnO}$ using sunlight.

\subsection{Effect of Initial Dye Concentration}

The photocatalytic degradation of dye depended on its initial concentration, and it was necessary to investigate the effect of dye concentrations in view of their practical application. The solar photocatalytic degradation with different initial $\mathrm{MB}$ dye concentrations in the presence of $\mathrm{CuO} / \mathrm{ZnO}$ was studied, as shown in Figure 6. It was observed that as initial MB dye concentrations increased from $5 \mathrm{mg} / \mathrm{L}$ to $20 \mathrm{mg} / \mathrm{L}$, the dye degradation efficiency gradually decreased [36,37]. In this study, methylene blue of $10 \mathrm{mg} / \mathrm{L}$ solution was selected to evaluate the photodegradation of dye under sunlight, because of the high concentration of real wastewater. 


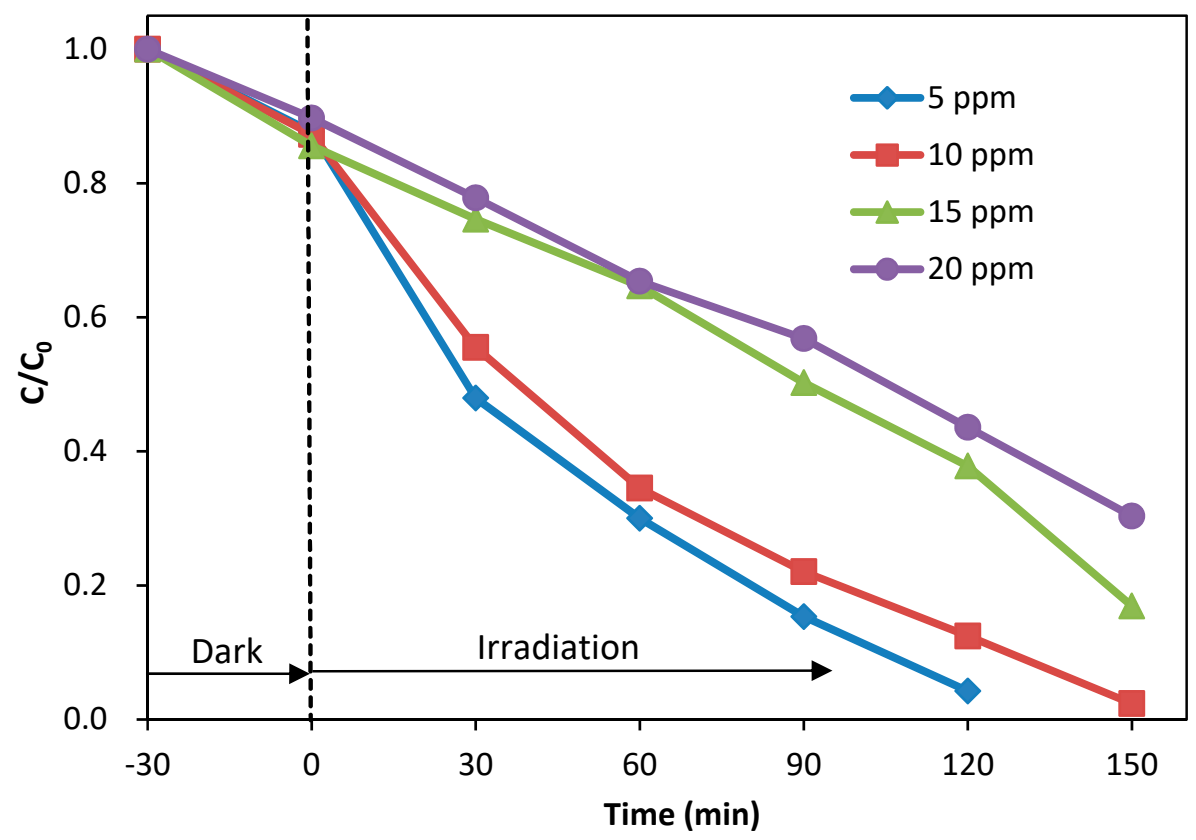

Figure 6. Effect of initial dye concentration on the photodegradation of $\mathrm{MB}$ with $\mathrm{CuO} / \mathrm{ZnO}$.

\subsection{Role of Reactive Species}

The scavengers of $d i$-ammonium oxalate monohydrate (AO), 2-propanol, and ascorbic acid (AA) were used to identify the reactive species for MB photodegradation. The three scavengers' effect on the $\mathrm{MB}$ photodegradation with $\mathrm{CuO} / \mathrm{ZnO}$ is displayed in Figure 7. From the results (Figure 7), it was observed that with the addition of 2-propanol, $\mathrm{AO}$, and $\mathrm{AA}$ as a scavenger, photocatalytic degradation dropped from $66 \%$ (without scavenger) to $23 \%\left({ }^{\bullet} \mathrm{O}_{2}{ }^{-}\right), 13 \%\left({ }^{\circ} \mathrm{OH}\right)$, and $53 \%\left(\mathrm{~h}^{+}\right)$for $1 \mathrm{~h}$, while the photocatalytic activity significantly decreased from $88 \%$ (without scavenger) to $29 \%\left({ }^{\bullet} \mathrm{O}_{2}{ }^{-}\right), 37 \%\left({ }^{\bullet} \mathrm{OH}\right)$, and $79 \%\left(\mathrm{~h}^{+}\right)$for $2 \mathrm{~h}$ irradiation, respectively. It can be surmised that the important roles played for the photodegradation of $\mathrm{MB}$ were by ${ }^{\bullet} \mathrm{O}_{2}{ }^{-}$and ${ }^{\bullet} \mathrm{OH}$ radicals, while a minor role was played by the $\mathrm{h}^{+}$ radical in the degradation process under sunlight [38].

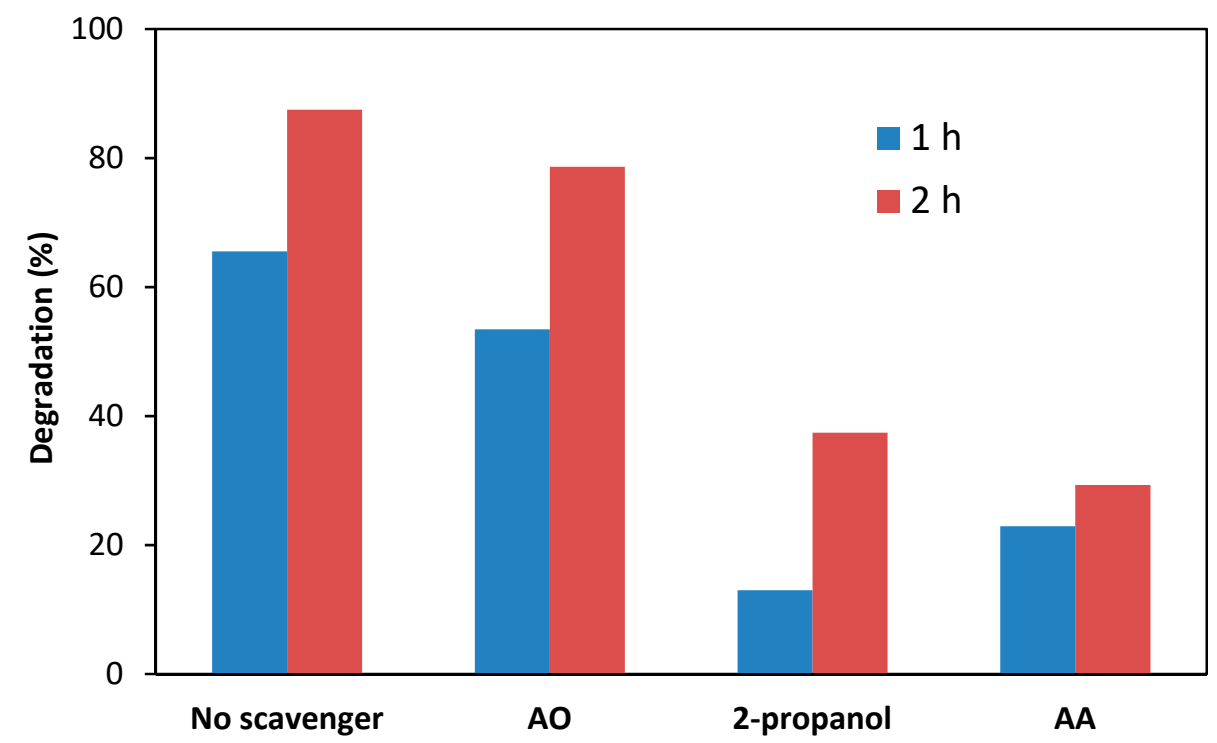

Figure 7. Effects of scavengers on the photodegradation of $\mathrm{MB}$ with $\mathrm{CuO} / \mathrm{ZnO}$ using sunlight. 


\subsection{Degradation Mechanism}

The schematic diagram (Figure 8) shows the photodegradation mechanism of MB with $\mathrm{CuO} / \mathrm{ZnO}$ nanocomposite. $\mathrm{CuO}$ and $\mathrm{ZnO}$ formed a heterojunction, which assisted the separation of photogenerated carriers [39]. The conduction band (CB) potentials were $-0.43 \mathrm{eV}$ for $\mathrm{CuO}$ and $-0.15 \mathrm{eV}$ for $\mathrm{ZnO}$ vs Normal Hydrogen Electrode (NHE) [40]. The band gaps of $\mathrm{CuO}$ and $\mathrm{ZnO}$ were 1.4 and $3.23 \mathrm{eV}$, respectively [41,42]. During sunlight irradiation, $\mathrm{CuO}$ and $\mathrm{ZnO}$ were excited to generate electrons and holes at the CB and the valence band (VB), respectively, as displayed in Figure 8, since the band positions of $\mathrm{ZnO}$ were below the $\mathrm{CB}$ and $\mathrm{VB}$ of $\mathrm{CuO}$. The photoexcited electrons transferred from $\mathrm{CuO}$ to $\mathrm{ZnO}$, whereas the holes migrated from $\mathrm{ZnO}$ to $\mathrm{CuO}$. [43]. Then, oxygen molecules in dye solution reacted with electrons to generate superoxide radical $\left({ }^{\bullet} \mathrm{O}_{2}{ }^{-}\right)$and the holes combined with $\mathrm{H}_{2} \mathrm{O}$ to produce hydroxyl radical $\left({ }^{\bullet} \mathrm{OH}\right)$. Moreover, $\mathrm{MB}$ was directly oxidized by the holes at the $\mathrm{VB}$ of $\mathrm{CuO}[44,45]$. The strong oxidant radicals of ${ }^{\bullet} \mathrm{OH}$ and ${ }^{\bullet} \mathrm{O}_{2}{ }^{-}$readily oxidized the $\mathrm{MB}$ molecule. We proposed the following possible degradation mechanism of $\mathrm{MB}$ with $\mathrm{CuO} / \mathrm{ZnO}$ in the presence of sunlight.

$$
\begin{gathered}
\mathrm{ZnO}+h v \rightarrow \mathrm{ZnO}\left(\mathrm{e}_{\mathrm{CB}}^{-}+\mathrm{h}_{\mathrm{VB}}{ }^{+}\right) \\
\mathrm{e}^{-}(\mathrm{CB})+\mathrm{O}_{2} \rightarrow \mathrm{O}_{2}^{-} \\
\mathrm{h}^{+}(\mathrm{VB})+\mathrm{OH}^{-} \rightarrow{ }^{\bullet} \mathrm{OH} \\
\mathrm{O}_{2}{ }^{-}+\mathrm{MB} \rightarrow \text { degraded products } \\
\bullet \mathrm{OH}+\mathrm{MB} \rightarrow \text { degraded products } \\
\mathrm{h}^{+}(\mathrm{VB})+\mathrm{MB} \rightarrow \text { degraded products }
\end{gathered}
$$

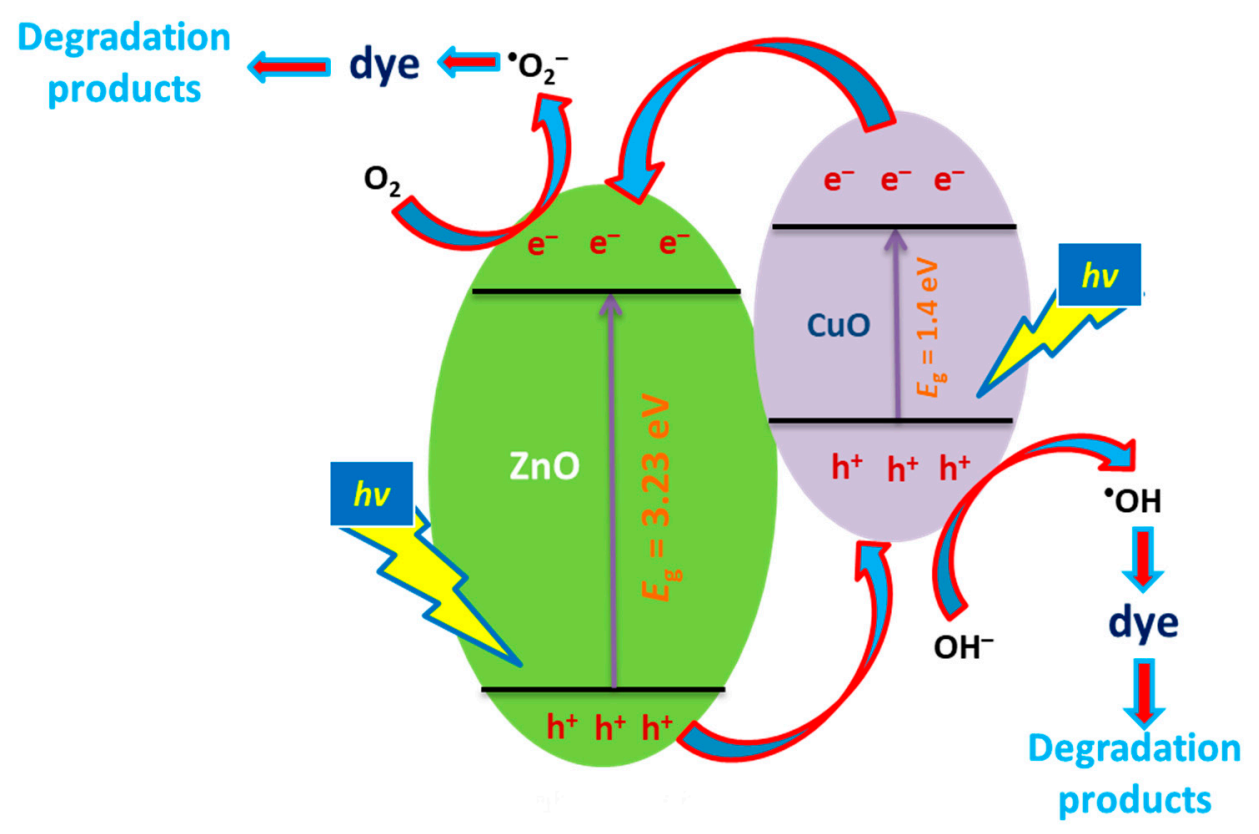

Figure 8. The possible degradation mechanism of $\mathrm{CuO} / \mathrm{ZnO}$ photocatalyst using sunlight.

\subsection{Mineralization of Dye}

The evaluation of mineralization of MB was investigated by measuring the total organic carbon (TOC). The TOC removal is presented in Figure 9a, showing the degradation of MB under sunlight irradiation. The TOC rapidly decreased with increased solar irradiation time up to $2 \mathrm{~h}$. After $7 \mathrm{~h}$ irradiation using $\mathrm{CuO} / \mathrm{ZnO}$, the mineralization of $\mathrm{MB}$ was observed at about $91 \%$ of TOC reduction. The chemical oxygen demand (COD) was an effective method, widely used for the measurement of 
photodegradation of organic dye [46]. The test was used to measure the total amount of oxygen needed for the oxidation of dye to produce carbon dioxide and water [47]. The COD value of MB of aqueous solution using $\mathrm{CuO} / \mathrm{ZnO}$ is described in Figure $9 \mathrm{~b}$. With increased solar irradiation time, COD values sharply decreased up to $3 \mathrm{~h}$, and COD reduction was about $84 \%$ after $7 \mathrm{~h}$. The reduction of COD and TOC values after the solar irradiation of MB indicated that methylene blue molecule was mineralized.
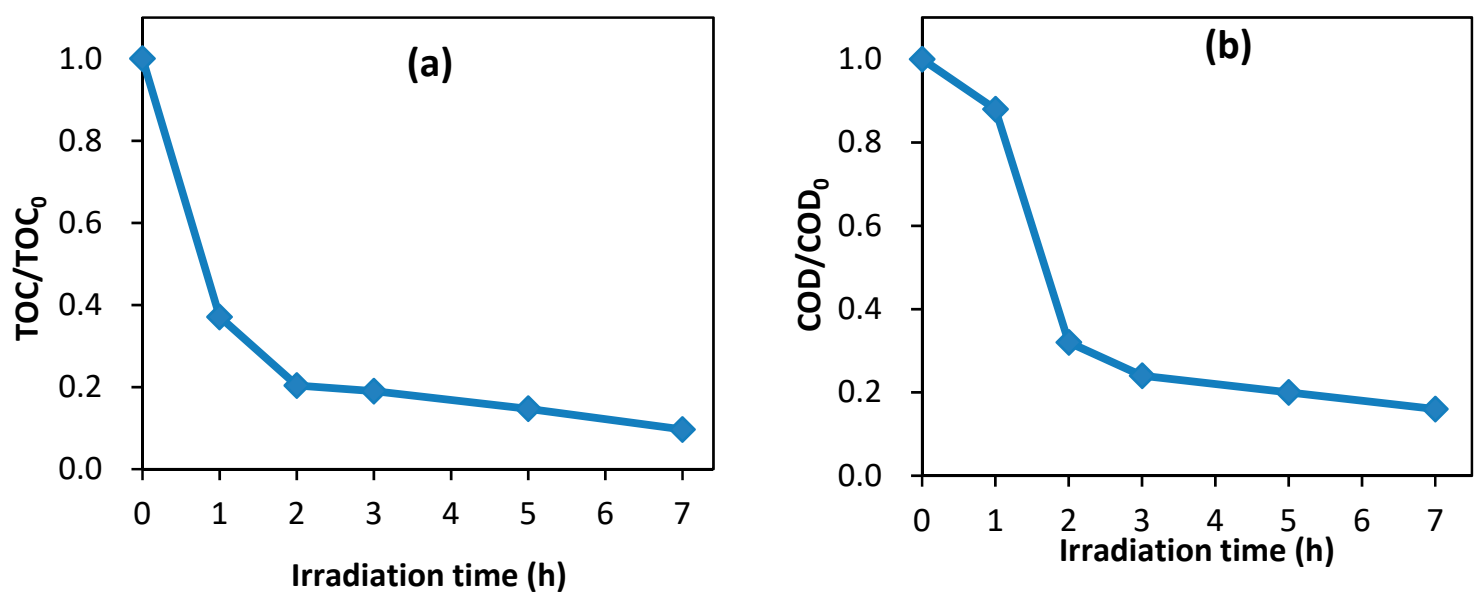

Figure 9. Mineralization of $\mathrm{MB}$ during the photodegradation with $\mathrm{CuO} / \mathrm{ZnO}$ using sunlight. (a) total organic carbon (TOC) and (b) chemical oxygen demand (COD).

\section{Conclusions}

The low-cost mechanochemical combustion method was used to synthesize $\mathrm{CuO} / \mathrm{ZnO}$ nanocomposites with various $\mathrm{Cu}$ contents. The best photodegradation efficiency was obtained with $5 \mathrm{wt} \% \mathrm{CuO} / \mathrm{ZnO}$. The values of $\mathrm{MB}$ degrading with un-doped $\mathrm{ZnO}$ and $\mathrm{CuO} / \mathrm{ZnO}$ were measured to be $81 \%$ and $98 \%$ respectively, after $2 \mathrm{~h}$ of solar irradiation. $\mathrm{MB}$ photodegradation with $\mathrm{CuO} / \mathrm{ZnO}$ under sunlight occurred mainly with ${ }^{\bullet} \mathrm{O}_{2}{ }^{-}$and ${ }^{\bullet} \mathrm{OH}$ radicals, while the $\mathrm{h}^{+}$radical showed a minor role in the process. The decrease of TOC values of MB indicated the mineralization in the photocatalytic process. Therefore, sunlight photodegradation technology may be a more effective technique for textile wastewater treatment than photodegradation with artificial and expensive Hg-Xe lamp.

Author Contributions: M.A.I.M. conceived and designed the experiments and wrote the paper. A.A.M.S. performed the experiments. S.M.M., J.H., and R.I. analyzed the results.

Funding: This research was funded by the University Grants Commission of Bangladesh, grant number 6(76)UGC/S\&T/Chemistry-02/2018/3577.

Acknowledgments: The authors are grateful to the Centre for Advanced Research in Sciences (CARS), University of Dhaka, Bangladesh for providing partial analytical support.

Conflicts of Interest: The authors declare no conflict of interest.

\section{References}

1. Mu, J.; Shao, C.; Guo, Z.; Zhang, Z.; Zhang, M.; Zhang, P.; Chen, B.; Liu, Y.C. High photocatalytic activity of $\mathrm{ZnO}-$ carbon nanofiber heteroarchitectures. ACS Appl. Mater. Interfaces 2011, 3, 590-596. [CrossRef] [PubMed]

2. Molla, M.A.I. Development of Advanced Technology for Photocatalytic Degradation of Organic Pollutants in Wastewater. Ph.D. Thesis, Mie University, Tsu, Japan, 2018.

3. Zangeneh, H.; Zinatizadeh, A.A.L.; Habibi, M.; Akia, M.; Isa, M.H. Photocatalytic oxidation of organic dyes and pollutants in wastewater using different modified titanium dioxides: A comparative review. J. Ind. Eng. Chem. 2015, 26, 1-36. [CrossRef]

4. Yulizar, Y.; Bakri, R.; Apriandanu, D.O.B.; Hidayat, T. ZnO/CuO nanocomposite prepared in one-pot green synthesis using seed bark extract of Theobroma cacao. Nano Struct. Nano Objects 2018, 16, 300-305. [CrossRef] 
5. Vidic, J.; Stankic, S.; Haque, F.; Ciric, D.; Le Goffic, R.; Vidy, A.; Jupille, J.; Delmas, B. Selective antibacterial effects of mixed ZnMgO nanoparticles. J. Nanopart. Res. 2013, 15, 1595-1605. [CrossRef] [PubMed]

6. Lu, P.; Zhou, W.; Li, Y.; Wang, J.; Wu, P. Abnormal room temperature ferromagnetism in $\mathrm{CuO} / \mathrm{ZnO}$ nanocomposites via hydrothermal method. Appl. Surf. Sci. 2017, 399, 396-402. [CrossRef]

7. Dorneanu, P.P.; Airinei, A.; Olaru, N.; Homocianu, M.; Nica, V.; Doroftei, F. Preparation and characterization of $\mathrm{NiO}, \mathrm{ZnO}$ and $\mathrm{NiO}-\mathrm{ZnO}$ composite nanofibers by electrospinning method. Mater. Chem. Phys. 2014, 148, 1029-1035. [CrossRef]

8. Hassanpour, M.; Hojaghan, H.S.; Niasari, M.S. Degradation of methylene blue and Rhodamine B as water pollutants via green synthesized $\mathrm{Co}_{3} \mathrm{O}_{4} / \mathrm{ZnO}$ nanocomposite. J. Mol. Liq. 2017, 229, 293-299. [CrossRef]

9. Hassanpour, M.; Salavati-Niasari, M.; Mousavi, S.A.; Safardoust-Hojaghan, H.; Hamadanian, M. CeO $2 / Z n O$ Ceramic nanocomposites, synthesized via microwave method and used for decolorization of dye. J. Nanostruct. 2018, 8, 97-106.

10. Saravanan, R.; Karthikeyan, S.; Gupta, V.K.; Sekaran, G.; Narayanan, V.; Stephen, A. Enhanced photocatalytic activity of $\mathrm{ZnO} / \mathrm{CuO}$ nanocomposite for the degradation of textile dye on visible light illumination. Mater. Sci. Eng. C 2013, 33, 91-98. [CrossRef]

11. Saravanan, R.; Gupta, V.K.; Mosquera, E.; Gracia, F. Preparation and characterization of $\mathrm{V}_{2} \mathrm{O}_{5} / \mathrm{ZnO}$ nanocomposite system for photocatalytic application. J. Mol. Liq. 2014, 198, 409-412. [CrossRef]

12. Saravanan, R.; Gupta, V.K.; Narayanan, V.; Stephen, A. Visible light degradation of textile effluent using novel catalyst $\mathrm{ZnO} / \gamma-\mathrm{Mn}_{2} \mathrm{O}_{3}$. J. Taiwan Inst. Chem. Eng. 2014, 45, 1910-1917. [CrossRef]

13. Li, B.; Wang, Y. Facile synthesis and photocatalytic activity of $\mathrm{ZnO}-\mathrm{CuO}$ nanocomposite. Superlattice Microst. 2010, 47, 615-623. [CrossRef]

14. Kuriakose, S.; Avasthi, D.K.; Mohapatra, S. Effects of swift heavy ion irradiation on structural, optical and photocatalytic properties of $\mathrm{ZnO}-\mathrm{CuO}$ nanocomposites prepared by carbothermal evaporation method. Beilstein J. Nanotechnol. 2015, 6, 928-937. [CrossRef]

15. Wang, A.; Chen, Z.; Zheng, Z.; Xu, H.; Wang, H.; Hu, K.; Yan, K. Remarkably enhanced sulfate radical-based photo-Fenton-like degradation of levofloxacin using the reduced mesoporous MnO@MnOx microspheres. Chem. Eng. J. 2019, 379, 122340. [CrossRef]

16. Gnanasekaran, L.; Hemamalini, R.; Saravanan, R.; Qin, J.; Yola, M.L.; Atar, N.; Gracia, F. Nanosized $\mathrm{Fe}_{3} \mathrm{O}_{4}$ incorporated on $\mathrm{TiO}_{2}$ surface for the enhanced photocatalytic degradation of organic pollutants. J. Mol. Liq. 2019, 287, 110967. [CrossRef]

17. Saravanan, R.; Agarwal, S.; Gupta, V.K.; Khan, M.M.; Gracia, F.; Mosquera, E.; Narayanan, V.; Stephen, A. Line defect $\mathrm{Ce}^{3+}$ induced $\mathrm{Ag} / \mathrm{CeO}_{2} / \mathrm{ZnO}$ nanostructure for visible-light photocatalytic activity. J. Photochem. Photobiol. A Chem. 2018, 353, 499-506. [CrossRef]

18. Jebaranjitham, J.N.; Mageshwari, C.; Saravanan, R.; Mu, N. Fabrication of amine functionalized graphene oxide-AgNPs nanocomposite with improved dispersibility for reduction of 4-nitrophenol. Compos. Part B 2019, 171, 302-309. [CrossRef]

19. Qin, J.; Yang, C.; Cao, M.; Zhang, X.; Saravanan, R.; Limpanart, S.; Ma, M.; Liu, R. Two dimensional porous sheet-like carbon-doped $\mathrm{ZnO} / \mathrm{g}-\mathrm{C}_{3} \mathrm{~N}_{4}$ nanocomposite with high visible-light photocatalytic performance. Mater. Lett. 2017, 189, 156-159. [CrossRef]

20. Saravanan, R.; Khan, M.M.; Gracia, F.; Qin, J.; Gupta, V.K.; Arumainathan, S. Ce ${ }^{3+}$-ion-induced visible-light photocatalytic degradation and electrochemical activity of $\mathrm{ZnO} / \mathrm{CeO}_{2}$ nanocomposite. Sci. Rep. 2016, 6, 31641. [CrossRef]

21. Yang, C.; Xue, Z.; Qin, J.; Sawangphruk, M.; Saravanan, R.; Zhang, X.; Liu, R. Visible-light Driven Photocatalytic $\mathrm{H}_{2}$ Generation and Mechanism Insights on $\mathrm{Bi}_{2} \mathrm{O}_{2} \mathrm{CO}_{3} / \mathrm{G}-\mathrm{C}_{3} \mathrm{~N}_{4}$ Z-scheme Photocatalyst. Phys. Chem. C 2019, 123, 4795-4804. [CrossRef]

22. Kanade, K.G.; Kale, B.B.; Baeg, J.O.; Lee, S.M.; Lee, C.W.; Moon, S.J.; Chang, H. Self-assembled aligned $\mathrm{Cu}$ doped $\mathrm{ZnO}$ nanoparticles for photocatalytic hydrogen production under visible light irradiation. Mater. Chem. Phys. 2007, 102, 98-104. [CrossRef]

23. Rooydell, R.; Brahma, S.; Wang, R.C.; Modaberi, M.R.; Ebrahimzadeh, F.; Liu, C.P. Cu doped ZnO nanorods with controllable $\mathrm{Cu}$ content by using single metal organicprecursors and their photocatalytic and luminescence properties. J. Alloys Compd. 2017, 691, 936-945. [CrossRef]

24. Hsieh, S.-H.; Ting, J.-M. Characterization and photocatalytic performance of ternary Cu-doped ZnO/Graphene materials. Appl. Surf. Sci. 2018, 427, 465-475. [CrossRef] 
25. Phiwdang, K.; Suphankij, S.; Mekprasart, W.; Pecharapa, W. Synthesis of CuO nanoparticles by precipitation method using different precursors. Energy Procedia 2013, 34, 740-745. [CrossRef]

26. Jun, S.T.; Choi, G.M. Composition dependence of the electrical conductivity of $\mathrm{ZnO}(\mathrm{n})-\mathrm{CuO}(\mathrm{p}) \mathrm{ceramic}$ composite. J. Am. Ceram. Soc. 1998, 81, 695-699. [CrossRef]

27. Zhang, D. Synthesis and characterization of ZnO-doped cupric oxides and evaluation of their photocatalytic performance under visible light. Transit. Met. Chem. 2010, 35, 689-694. [CrossRef]

28. Molla, M.A.I.; Furukawa, M.; Tateishi, I.; Katsumata, H.; Kaneco, S. Studies of effects of calcination temperature on the crystallinity and optical properties of Ag-doped $\mathrm{ZnO}$ nanocomposites. J. Compos. Sci. 2019, 3, 18. [CrossRef]

29. Benavente, E.; Duran, F.; Sotomayor-Torres, C.; Gonzalez, G. Heterostructured layered hybrid ZnO/MoS 2 nanosheets with enhanced visible light photocatalytic activity. J. Phys. Chem. Solids 2018, 113, 119-124. [CrossRef]

30. Su, J.; Zhu, L.; Geng, P.; Chen, G. Self-assembly graphitic carbon nitride quantum dots anchored on $\mathrm{TiO}_{2}$ nanotube arrays: An efficient heterojunction for pollutants degradation under solar light. J. Hazard. Mater. 2016, 316, 159-168. [CrossRef] [PubMed]

31. Lamba, R.; Umar, A.; Mehta, S.K.; Kansal, S.K. $\mathrm{Sb}_{2} \mathrm{O}_{3}-\mathrm{ZnO}$ nanospindles: A potential material for photocatalytic and sensing applications. Ceram. Int. 2015, 41, 5429-5438. [CrossRef]

32. Khana, S.A.; Noreen, F.; Kanwal, S.; Iqbal, A.; Hussain, G. Green synthesis of ZnO and Cu-doped ZnO nanoparticles from leaf extracts of Abutilon indicum, Clerodendrum infortunatum, Clerodendrum inerme and investigation of their biological and photocatalytic activities. Mater. Sci. Eng. C 2018, 82, 46-59. [CrossRef] [PubMed]

33. Saravanakkumar, D.; Sivaranjani, S.; Kaviyarasu, K.; Ayeshamariam, A.; Ravikumar, B.; Pandiarajan, S.; Veeralakshmi, C.; Jayachandran, M.; Maaza, M. Synthesis and characterization of ZnO-CuO nanocomposites powder by modified perfume spray pyrolysis method and its antimicrobial investigation. J. Semicond. 2018, 39, 033001. [CrossRef]

34. Ma, G.; Liang, X.; Li, L.; Qiao, R.; Jiang, D.; Ding, Y.; Chen, H. Cu-doped zinc oxide and its polythiophene composites: Preparation and antibacterial properties. Chemosphere 2014, 100, 146-151. [CrossRef] [PubMed]

35. Molla, M.A.I.; Furukawa, M.; Tateishi, I.; Katsumata, H.; Kaneco, S. Fabrication of Ag-doped ZnO by mechanochemical combustion method and their application into photocatalytic Famotidine degradation. J. Environ. Sci. Health Part A 2019, 54, 914-923. [CrossRef] [PubMed]

36. Kaneco, S.; Li, N.; Itoh, K.-K.; Katsumata, H.; Suzuki, T.; Ohta, K. Titanium dioxide mediated solar photocatalytic degradation of thiram in aqueous solution: Kinetics and mineralization. Chem. Eng. J. 2009, 148, 50-56. [CrossRef]

37. Molla, M.A.I.; Ahsan, S.; Tateishi, I.; Furukawa, M.; Katsumata, H.; Suzuki, T.; Kaneco, S. Degradation, Kinetics, and Mineralization in the solar photocatalytic treatment of aqueous amitrole solution with titanium dioxide. Environ. Eng. Sci. 2018, 35, 401-407. [CrossRef]

38. Wang, A.; Wang, H.; Deng, H.; Wang, S.; Shi, W.; Yi, Z.; Qiu, R.; Yan, K. Controllable synthesis of mesoporous manganese oxide microsphere efficient for photo-Fenton-like removal of fluoroquinolone antibiotics. Appl. Catal. B Environ. 2019, 248, 298-308. [CrossRef]

39. Chabri, S.; Dhara, A.; Show, B.; Adak, D.; Sinha, A.; Mukherjee, N. Mesoporous CuO-ZnO p-n heterojunction based nanocomposites with high specific surface area for enhanced photocatalysis and electrochemical sensing. Catal. Sci. Technol. 2016, 6, 3238-3252. [CrossRef]

40. Yang, L.; Xie, C.S.; Zhang, G.Z.; Zhao, J.W.; Yu, X.L.; Zeng, D.W.; Zhang, S.P. Enhanced response to $\mathrm{NO}_{2}$ with $\mathrm{CuO} / \mathrm{ZnO}$ laminated heterostructured configuration. Sens. Actuator B 2014, 195, 500-508. [CrossRef]

41. Alsabahi, J.; Bora, T.; Alabri, M.; Dutta, J. Efficient visible light photocatalysis of benzene, toluene, ethylbenzene and xylene (BTEX) in aqueous solutions using supported zinc oxide nanorods. PLoS ONE 2017, 12, e0189276.

42. Hansen, B.J.; Kouklin, N.; Lu, G.H.; Lin, I.; Chen, J.H.; Zhang, X. Transport, analyte detection, and opto-electronic response of p-Type CuO nanowires. J. Phys. Chem. C 2010, 114, 2440-2447. [CrossRef]

43. Zhang, J.N.; Chen, T.H.; Yu, J.H.; Liu, C.; Yang, Z.B.; Lu, H.B.; Yin, F.; Gao, J.Z.; Liu, Q.R.; Zhang, X.W.; et al. Enhanced photocatalytic activity of flowerlike $\mathrm{CuO}-\mathrm{ZnO}$ nanocomposites synthesized by one-step hydrothermal method. J. Mater. Sci. 2016, 27, 10667-10672. [CrossRef] 
44. Harish, S.; Archana, J.; Sabarinathan, M.; Navaneethan, M.; Nisha, K.D.; Ponnusamy, S.; Muthamizhchelvan, C.; Ikeda, H.; Aswal, D.K.; Hayakawa, Y. Controlled structural and compositional characteristic of visible light active $\mathrm{ZnO} / \mathrm{CuO}$ photocatalyst for the degradation of organic pollutant. Appl. Surf. Sci. 2017, 418, 103-112. [CrossRef]

45. Wu, F.S.; Wang, X.H.; Hu, S.Z.; Hao, C.; Gao, H.W.; Zhou, S.S. Solid-state preparation of CuO/ZnO nanocomposites for functional supercapacitor electrodes and photocatalysts with enhanced photocatalytic properties. Int. J. Hydrogen Energy 2017, 42, 30098-30108. [CrossRef]

46. Li, J.; Chen, C.; Zhao, J.; Zhu, H.; Orthman, J. Photodegradation of dye pollutants on $\mathrm{TiO}_{2}$ nanoparticles dispersed in silicat;e UV-Vis irradiation. Appl. Catal. B Environ. 2002, 37, 331-338. [CrossRef]

47. Jain, R.; Shirkarwar, S. Removal of hazardous dye Congo-red removal from waste material. J. Hazard. Mater. 2008, 152, 942-948. [CrossRef]

(C) 2019 by the authors. Licensee MDPI, Basel, Switzerland. This article is an open access article distributed under the terms and conditions of the Creative Commons Attribution (CC BY) license (http://creativecommons.org/licenses/by/4.0/). 